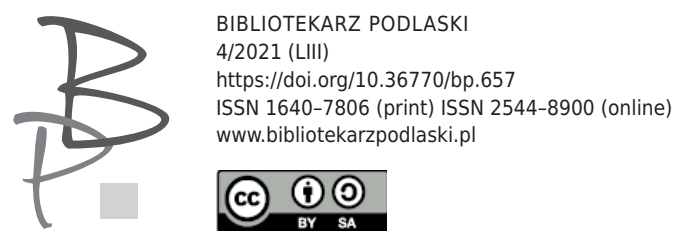

Agnieszka Czajkowska*

Uniwersytet Ostrawski, Czechy / University of Ostrava, Czech Republic

ORCID: 0000-0001-8448-023X

\title{
„Gdzież jest, poeto, ocalenie...?"
}

[Rec. Tadeusz Miciński i ludzie epoki. [Studia], redakcja naukowa Marcin Bajko, Jarosław Ławski, Urszula M. Pilch, Temida 2, UwB, Białystok 2019, s. 443, ISBN 978-83-65696-49-6]

"Oh, poet, where is the salvation...?"

[rev. Tadeusz Miciński and the People of the Age. Studies, scientific editors: Marcin Bajko, Jarosław Ławski, Urszula M. Pilch, Temida 2, UwB, Białystok 2019, 443 pgs., ISBN 978-83-65696-49-6]

Abstract This article is a review of the book Tadeusz Miciński i ludzie epoki. Studia [Tadeusz Miciński and the People of the Age. Studies] under the scientific editorship of Marcin Bajko, Jarosław Ławski and Urszula M. Pilch, published by Temida 2 publishing house in Białystok in 2019. The researcher notes that the analysed book centres around the motif of "salvation", that it is possible thanks to the poets dialoguing with the protagonist of the book, Tadeusz Miciński, through the multiplication of presence - translation into other languages and cultures, through discovering in the interpretation the traces of the author's intellectual wanderings across other cultures and religions, thanks to contemporary means of communication resonating the work, and finally thanks to human memory and its testimonies. In conclu-

* Agnieszka Czajkowska - prof. dr hab., historyk literatury; pracuje na Uniwersytecie Ostrawskim w Czechach, przez wiele lat związana z Uniwersytetem Humanistyczno-Przyrodniczym im. Jana Długosza w Częstochowie; autorka kilku monografii, m.in. „Poeci uczeni”: związki nauki i literatury w twórczości romantyków (2014). 
sion, the researcher recommends the book as an indispensable tool not only to those interested in the author of Nietota [The Firmoss], but also in the literature of Polish modernism in general.

Keywords: Miciński, review, salvation, $20^{\text {th }}$-century poetry, Polish culture.

Użyty w tytule cytat z Czesława Miłosza można odnosić, poza kontekstami biograficznymi i intelektualnymi, związanymi z autorem Traktatu moralnego, do każdego właściwie twórcy, czytanego po latach i „próbowanego" w retortach zmiennych mód, upodobań czy literackich gustów. Szczególnie jednak wypada powiązać słowa noblisty z książką ukazującą się w 100-lecie śmierci Tadeusza Micińskiego i stanowiącą drugą część cyklu badawczego „Młoda Polska: rewizje, reinterpretacje”, zainicjowanego przez Katedrę Badań Filologicznych „Wschód - Zachód” z Wydziału Filologicznego Uniwersytetu w Białymstoku, Katedrę Historii Literatury Pozytywizmu i Młodej Polski z Wydziału Polonistyki Uniwersytetu Jagiellońskiego oraz Dział Naukowy Książnicy Podlaskiej im. Łukasza Górnickiego w Białymstoku. Praca jest także kontrapunktem dla czterotomowej edycji pism rozproszonych pisarza młodopolskiego, w którą - w związku z grantem NPRH - zaangażowani byli redaktorzy i niektórzy z autorów tomu. Monografia została zadedykowana Profesorowi Wojciechowi Gutowskiemu, wybitnemu znawcy twórczości pisarza.

Gdzież zatem szukać ocalenia poety, Tadeusza Micińskiego, który nie znalazł poczesnego miejsca w kanonie literackim, ani nie cieszył się zbytnią popularnością wśród współczesnych sobie czytelników, choć z pewnością w swoim czasie budził gwałtowne sądy i sprzeczne opinie? Przygotowana w białostockiej Katedrze Badań Filologicznych „Wschód-Zachód” książka jest niezwykle interesującą, ale też dość zaskakującą odpowiedzią na tak zadane pytanie, zwłaszcza jeżeli wziąć pod uwagę jej kompozycję... Czteroczęściową publikację otwierają i zamykają teksty, które symbolicznie uśmiercają poetę. Wprowadza w świat autora Nietoty praca Anny Wydryckiej, prezentująca różne wersje śmierci poety i pieczołowicie, z wykorzystaniem bogatej dokumentacji, rekonstruująca ich okoliczności. Autorka czyta wspomnienia, materiały prasowe, bada mapy w poszukiwaniu nazw miejscowości związanych z ostatnimi podróżami Micińskiego w ogarniętej rewolucyjnym cha- 
osem Rosji i z domniemanymi tragicznymi wydarzeniami, które zakończyły się śmiercią poety. Wyprawa jego śladami wiedzie autorkę do odległej Mohylewszczyzny, z miejscowością Wydranka, i pozwala poznać jej mieszkankę, Marię Baranowską-Dohrn, która dobrze znała autora Xiędza Fausta i polecała jego twórczość w swoich listach do Paula Claudela. Autorka tekstu stawia tezę o śmierci Micińskiego w Wydrance w kwietniu lub maju 1918 roku i wskazuje miejsce jego pochówku - Małynicze Małe, nie przesądzając sprawy motywów i winowajców zabójstwa. Ów niezwykle przekonujący wstęp do lektury Micińskiego jest wartościowy nie tylko w odniesieniu do poety, ale także ze względu na przywołaną postać Marii Baranowskiej-Dohrn, jej pełnego pasji życia i gospodarowania na ziemiach białoruskich.

Monografię zamyka analiza epitafiów literackich, poświęconych poecie w dziesiątą i dwudziestą rocznicę jego śmierci. Różnie oceniany za życia twórca w 1928 roku doczekał się - przekonuje Katarzyna Klewinowska sporo pochlebnych opinii, pisanych przez znaczących pisarzy (na przykład Stanisława Vincenza) i publikowanych w prasie. Im dłuższy czas mijał od śmierci, tym tonacja wypowiedzi zmieniała się, a pochwały zyskiwały na sile, o czym świadczy rekonesans autorki studium przeprowadzony w prasie z 1938 roku.

Przyznać trzeba, iż zwieńczenie książki nie wybrzmiewa tak wyraziście, jak jej Wstęp, którego autorem jest Jarosław Ławski, nazywający Micińskiego ostatnim ucieleśnieniem Mickiewiczowskiego wzoru postawy czynnej i w ten niezwykle brawurowy sposób nadający ton i kierunek interpretacji dzieła autora Nietoty. Finał nie ma również tej siły przekonywania, co inicjujący część naukową publikacji tekst Anny Wydryckiej. Może to konsekwencja nieco zbyt częstego operowania epitetem kontrowersyjnym wobec osoby i twórczości Micińskiego? Może efekt niezręcznego sformułowania: „zainteresowanie nią [twórczością Tadeusza Micińskiego - A. Cz.] stale ewaluowało" (s. 388), które, zapewne zwykła literówka, burzy ład wywodu i mimowolnie staje się znakiem naszego czasu - smutnym symbolem rzeczywistości akademickiej, w której wszyscy jesteśmy poddawani nieustannej ewaluacji?

Budowa monografii jest czteroczęściowa. Część pierwsza nosi tytuł $\mathrm{Pi}$ sarz i oprócz wspomnianego tekstu Anny Wydryckiej składa się z kolejnych czterech, niezwykle frapujących rozdziałów. Ukazują one Micińskiego w bogatym kontekście geograficznym i kulturowym - od japonizmów, poprzez 
konotacje angielskie, belgijsko-rosyjskie aż po amerykańskie. Tematem przewodnim zgromadzonych prac jest tożsamość autora Nietoty, bogata, skomplikowana, łącząca w sobie rozmaite role osoby żyjącej w nienasyceniu, żywiołowo aktywnej, niemal rozpolitykowanej, a jednocześnie autoironicznej, niepozbawionej dystansu do siebie. Odczytywanie Micińskiego w różnych lustrach pozwala autorkom (Urszuli M. Pilch, Hannie Ratusznej, Annie Janickiej) i jednemu autorowi (Jarosławowi Ławskiemu) ukazać go jako współtwórcę „ducha epoki” i jako artystę o duszy chłonnej, z łatwością adaptującej wszelkie nowości, otwartej na egzotykę i wszelką odmienność, a przy tym niezwykle świadomego własnej roli jako poety. Teksty dają przy tym możliwość zobrazowania kolejnych etapów drogi twórczej Micińskiego i poznać jego sposób myślenia i działania.

Ta część monografii poświęcona Micińskiemu jest szczególna - badacze czytają go w afekcie, z zaangażowaniem i autentycznym współodczuwaniem. Osobista perspektywa jest szczególnie widoczna w tekście Anny Janickiej, rekonstruującym globalny aspekt myślenia Micińskiego, wynikający z wykroczenia poza europejski zaścianek i umożliwiający niezwykłą perspektywę widzenia losów Polski. Profetyzm i geopolityczna przenikliwość poety, uważnie odczytane z wersów poematu, umiejscowiona została przez autorkę w kontekście przemian w polskim obrazie Ameryki. W studiach Jarosława Ławskiego (,Los Verhaerena” Tadeusza Micińskiego. Manifest z epoki katastrof), Hanny Ratusznej (,...i jak motyle w barwnym ogrodzie..." - uwagi o japonizmie w twórczości Tadeusza Micińskiego) i Urszuli M. Pilch (,,Biora mnie podobno za Anglika”. Tożsamość „,ja' w liryce i publicystyce Tadeusza Micińskiego) emocje są bardziej skryte, ale znać, że pulsują pod powierzchnią fachowych analiz, i tylko zobrazowane w pracach dziwne splątanie losów osób, zaskakujące spotkania tekstów, wątków oraz motywów przywołuje zdumienie i, często, zachwyt ich autorów nad niespodziewanym „odkryciem” Micińskiego. Jest z pewnością dużą zasługą pasji badawczej i piór (klawiatur) poszczególnych autorów, że czytelnik może poznawać autora Nietoty niczym osobę bliską, współczesną sobie, budzącą uznanie, ale także prawdziwe wzruszenie.

Część druga monografii, zatytułowana Literackie dialogi i polifonie, składa się z siedmiu rozdziałów. To szeroka perspektywa pokrewieństw, powinowactw i dialogów w literaturze, publicystyce i muzyce, w których autorzy 
lokują twórczość autora Nietoty. Tekst Anny Czabanowskiej-Wróbel dopisuje niejako brakujące ogniwo w relacjach Micińskiego i Iwaszkiewicza. Jest nim twórczość muzyczna Karola Szymanowskiego, bazująca na parafrazach wschodnich testów dokonywanych przez autora Nietoty. Stanowi ona miejsce przecięcia się światów obu poetów i punkt początkowy refleksji autorki. Anna Kieżuń jest autorką spostrzeżeń na temat powinowactw ideowych Micińskiego i Artura Górskiego. I w tym rozdziale kontekstem dla spotkania wymienionych w tytule autorów jest osoba trzecia - znakomity mickiewiczolog, edytor dzieł wieszcza, Stanisław Pigoń. Dzięki uczonemu, który redagował pracę Miscellanea literackie 1864-1910 i poprosił Górskiego o napisanie wspomnienia o Micińskim, możemy oglądać osobę poety oczami przyjaciela i współmieszkańca w latach krakowskich. Górski (i Miciński) staje się rzecznikiem Młodej Polski aktywnej, świadomej w swym rozwoju, nie-przybyszewskiej.

Kolejne studia (Fryderyka Nguyen, Grzegorza Iglińskiego, Pawła Wojciechowskiego, Ireny Szewczenko i Heleny Nielepko) prezentują kolejno Micińskiego w zbieżności z Witkacym (teoria psychiki), ze Zdzisławem Klemensem Dębickim, Janem Pietrzyckim, Anatolem Sternem, Stanisławem Przybyszewskim, szwedzkim pisarzem Gustafem af Geijerstamem, pisarzami rosyjskimi oraz z białoruskim poetą Janką Kupałą. Te rozmaite konteksty ukazują nie tylko rozległą skalę zainteresowań Micińskiego literaturą ówczesnej Europy, ale pozwalają również wybrzmieć utworom poety pisanym przez niego w językach obcych oraz utworom obecnych w innych kulturach dzięki tłumaczeniom.

Część trzecia monografii, eufemistycznie zatytułowana Niespokojne drogi: recepcja, ukazuje życie poezji Micińskiego we współczesnej muzyce popularnej, ściślej - jej szczególnie głośnej odmianie. Otwierają ten fragment dwa opracowania poświęcone obecności poety w subkulturze metalowej. Powyższą problematykę porusza jeszcze jeden tekst zamieszczony w tej części, Mariusza Doeringa W cieniu jutrzenki-muzyczne konotacje z czcicielem tajemnic, będący swobodną impresją na temat spotkań autora z Micińskim granym i śpiewanym. Rozdział zatytułowany Tadeusz Miciński jako poeta subkultury metalowej, którego autorem jest Marcin Bajko, uczciwie wskazuje na zjawisko charakterystyczne w ogóle dla kultury masowej i dla zasad funkcjonowania w niej tekstów czy zjawisk wziętych z tzw. kultury wysokiej. Potoczną, popularną recepcję cechuje wybiórczość czy wręcz niezrozumienie 
postawy twórcy, który - w obcej dla siebie estetyce - niekiedy staje się rzecznikiem (by nie rzec zakładnikiem) cudzych idei i przekonań. W przypadku poezji autora Nietoty elementem, który przyciąga autorów i wykonawców muzyki metalowej, jest wątek lucyferyczny, odczytywany w duchu satanistycznym. Również tekst Mateusza Żyły, posiłkując się koncepcją pola literackiego Pierre'a Bourdieu, wskazuje na przesunięcie twórczości Micińskiego w „metalowe" konteksty muzyczno-obyczajowe. Autor chyba nie do końca zręcznie pisze w nim o muzyce ,wykrzyku duszy” (s.335), czy o tym, co by pisarz „raczył śnić” (s. 335). Kolejny tekst, Andrzeja Borkowskiego, ukazuje życie poezji Micińskiego w muzyczno-scenicznych wykonaniach umieszczonych w popularnym kanale internetowym. Internetem zajmuje się również Marek Kurkiewicz. Zamyka tę część wspomniane już „funeralne” rozpoznanie Katarzyny Klewinowskiej.

Ostatnia część, zatytułowana Postscriptum, jest zapisem panelu, który odbył się 12 października 2018 roku w Książnicy Podlaskiej im. Łukasza Górnickiego. Wzięli w nim udział: prowadzący spotkanie prof. Jarosław Ławski i dr Marcin Bajko oraz prof. Anna Czabanowska-Wróbel, dr hab. Elżbieta Flis-Czerniak, prof. Hanna Ratuszna, dr Helena Nielepko, prof. Marek Kurkiewicz, prof. Anna Kieżuń, dr Paweł Wojciechowski, prof. Anna Wydrycka, mgr Mateusz Żyła. Książkę dopełniają zdjęcia z konferencji naukowej, której pokłosiem jest recenzowany tom. Całość rekomendują recenzenci, których sądy redaktorzy umieścili na okładce.

Przedstawiony tom, skromnie i, by tak rzec, nawiasowo podpisany „studia", jest imponujący pod względem wielości perspektyw, w których została ujęta twórczość Tadeusza Micińskiego. Znacznie poszerza wiedzę na temat poety i jej nie zawsze oczywistych kontekstów. Książka imponuje dopracowaną szatą graficzną. Koncept okładki i jej bardzo młodopolskie barwy mogą wzbudzić prawdziwy zachwyt.

Gdyby na koniec pokusić się o odpowiedź na postawione w tytule pytanie, po lekturze książki poświęconej Tadeuszowi Micińskiemu należałoby wskazać wiele czynników zapewniających artyście ocalenie. Jest ono możliwe dzięki dialogującymi z nim poetami, poprzez zwielokrotnienie obecności - tłumaczenie na inne języki i kultury, poprzez odkrywanie w interpretacji tropów intelektualnych wędrówek autora szlakiem innych kultur i religii, dzięki współczesnym środkom komunikacji, rezonującym dzieło, wreszcie dzięki 
ludzkiej pamięci i jej świadectwom. Im więcej działań czytelników - takich jak projekt zbierający rozproszone okruchy dzieła, konferencja naukowa, publikacja efektów namysłu i dociekań interpretacyjnych - tym skuteczniejsza prezentacja nagromadzonych w tekstach koncepcji i nabrzmiałych w nich emocji. Wydaje się, że takich empatycznych i sprawczych czytelników, mimo istniejących już prac znakomitych interpretatorów, Tadeusz Miciński ciągle oczekiwał. W stulecie swojej śmierci otrzymał w prezencie książkę, która ocala nieznaną część jego istnienia.

\section{Bibliografia}

Bajko M., Heroiczna Apokalipsa. W kręgu idei i wyobraźni Tadeusza Micińskiego, Białystok 2012.

Bajko M., Sny niezwykłe o Polsce i o Europie. Diagnoza kultury w pismach Tadeusza Micińskiego u progu pierwszej wojny światowej, Kraków 2015.

Gutowski W., Między inicjacją a nicością. Studia i szkice o literaturze modernizmu, Bydgoszcz 2013.

Miciński T., Pisma rozproszone, red. M. Bajko, J. Ławski, t. II: Eseje i publicystyka 1909-1914, wstęp, opr. i przypisy W. Gutowski, U. M. Pilch, Białystok 2018.

Poezja Tadeusza Micińskiego. Interpretacje, red. A. Czabanowska-Wróbel, P. Próchniak, M. Stala, Kraków 2006.

Proza Tadeusza Micińskiego. Studia, wstęp J. Ławski, red. naukowa M. Bajko, W. Gutowski, J. Ławski, Białystok 2017.

Próchniak P., Pęknięty płomień. O pisarstwie Tadeusza Micińskiego, Lublin 2006. 
隆 